\title{
THE INFLUENCE OF INCOME INEQUALITIES ON SOCIO-ECONOMIC DEVELOPMENT IN THE EUROPEAN UNION
}

\author{
Michał Litwiński \\ Poznań University of Economics and Business, Poznań, Poland \\ e-mail: michal.litwinski@ue.poznan.pl \\ ORCID: 0000-0001-8143-6006 \\ (C) 2019 Michał Litwiński \\ This is an open access article distributed under the Creative Commons Attribution-NonCommercial- \\ -NoDerivs license (http://creativecommons.org/licenses/by-nc-nd/3.0/)
}

DOI: 10.15611/eada.2019.1.04

JEL Classification: D31, O11, O15, C32

\begin{abstract}
Recently, there has been observed intensified research on the impact of income inequalities on aspects of socio-economic development in the European Union. However, there are no comprehensive analyses concerning the relationship between these phenomena. Therefore the subject of the paper is the influence of income inequalities on socio-economic development. The author would like to verify the hypothesis that the character of the impact of income inequalities on socioeconomic development in the European Union is negative. Analysis was conducted for the European Union in 2004-2017 using the panel data model, also estimated was the synthetic indicator of socioeconomic development. The research conducted in the paper leads to ambiguous conclusions. On the one hand, inequalities measured for the whole distribution of income have no influence on socioeconomic development in the European Union. However, the income gap between the richest and the poorest hinders the mentioned phenomenon.
\end{abstract}

Keywords: income inequalities, socio-economic development, economic growth, panel model, Gini coefficient, S80/S20 ratio.

\section{Introduction}

In recent years one can observe the intensification of interest in the influence of income inequalities on particular aspects of socio-economic development in the European Union, e.g. economic growth, human capital and the natural environment. The impact of income concentration on these categories is generally believed to be negative [Thorbecke, Charumilind 2002; Galor 2000; Persson, Tabellini 1994; Fay 1993; Alesina et al. 2004; Birdsall 1999; Wilkinson 1996; Wildman 2003; Brunner, Marmot 1999; Cole et al. 1992; Hopkins, Kornienko 2010; Van Wilsem 2004; Becker 1993; Shaw, McKay 1942; Boyce 1994]. However, according to the best of this author's knowledge, no attempts to analyze overall relationship between two 
mentioned phenomena have been made so far. The only research concerned fragments of this relation, i.e. the influence of income dispersion on the level of education. Moreover, previous studies do not take into consideration the relations between social and economic scopes of analysis. Conducting research from the overall perspective, in regard of all aspects of socio-economic development altogether, could have a crucial impact on the results of analysis.

Therefore, the subject of this paper is the influence of income inequalities on socio-economic development. The author would like to verify the hypothesis that the character of the impact of income inequalities on socio-economic development in the European Union is negative.

Recognition of the character of this influence will enrich economics with knowledge concerning the factors of socio-economic development in the EU. This is crucial in the context of (1) the aim of reaching a high level of this phenomenon and (2) the important initiatives of the World Economic Forum in Davos that wants to alleviate income inequalities, simultaneously promoting socio-economic development [World Economic Forum 2018].

Analysis was carried out for the European Union in 2004-2017. Such length of time series is the consequence of the availability of data in Eurostat from which the information is obtained (this database contains the most complex and high-quality data for the EU member states). Moreover, in 2004 the greatest extension of the European Union to date took place, which resulted in the increase of the quality of statistics in a number of analyzed countries.

Research was carried out using the econometric model. Shortness of time series could be an obstacle in such analysis, so the author decided to employ the panel data model that allows to analyze data both in time and for countries - such a solution increases the number of observations. We considered specifications with fixed effects, random effects and time effects. The paper also estimated the synthetic indicator of socio-economic development. Income inequalities are measured by the Gini coefficient and S80/S20 ratio.

The basis for the econometric analysis is a review of literature concerning the problem of defining and measuring income inequalities and socio-economic development. The author also considered theories on the influence of the former on the latter.

\section{Definition and measurement of income inequalities and socio-economic development}

\subsection{Income inequalities}

In this article income inequalities are defined as follows: a situation in which the incomes of society's members (individuals, households or social groups) are not identical [OECD 2011]. Income inequalities are a feature of society that concerns 
only the distribution of incomes [Panek 2011]. This paper considered income inequalities between households - this is a popular approach in economic analyses [McKay 2002]. Moreover, the majority of databases offer time series only for this level - statistics for individuals are not available.

Inequalities will be measured on the basis of disposable income. The latter will be understood as "gross income less income tax, regular taxes on wealth, employees', self-employed and unemployed (if applicable) persons' compulsory social insurance contributions, employers' social insurance contributions and interhousehold transfers paid". This definition is proposed by the European Union [2003, p. 208] in association with the Survey of Income and Living Conditions (EU-SILC) that is carried out by all member states of the EU.

Such a definition is the most appropriate as it represents the actual level of income. Additionally, it encompasses all revenues, so differences in the understanding of income sources in various countries are not a problem anymore. In this paper adopting such a definition is also appropriate due to using the Eurostat database - this organization offers the longest reliable time series for European Union member states.

Income that is the basis for the measurement of inequalities should be recalculated in order to ensure comparability in time and between countries. The most popular solutions in this case are Purchasing Power Parity and the equivalence scale. Concerning the former, we used data according to the estimation proposed by Eurostat. As regards the latter, the modified equivalence scale was applied. This is also the solution suggested by Eurostat. This way of transforming income is not appropriate for all member states. However, Eurostat wants to ensure the international comparability of data, therefore it is necessary to use one equivalence scale for all countries [Brandolini 2007].

Different indicators of inequalities are proposed. Some of them are used to measure dispersion in the whole distribution of income (Theil index, Gini coefficient, Atkinson measure). The others could measure the distance between the richest and the poorest (decile ratio, modified quintile ratio, share of income by different income groups). It is necessary to take into consideration both types of indicators [Panek 2011].

The choice of the most appropriate ones should be made on the basis of axioms - features that ought to characterize the measures of income inequalities [Allison 1978; Subramanian 2004; Panek 2011; Amiel, Cowell 1992]. The Gini coefficient seems to be the most useful here. Additionally, it is the most popular (and available in official credible databases) indicator of income inequalities. However, this measure is based on the whole distribution of income, so it is sensitive to outliners [Brzeziński, Kostro 2010], therefore it will be appropriate to consider also an indicator that compares the situation of the richest and the poorest. In this paper, the S80/S20 ratio is adopted. According to Eurostat [2018], "The income quintile share ratio or the $\mathrm{S} 80 / \mathrm{S} 20$ ratio is $[\ldots]$ calculated as the ratio of total income 
received by the $20 \%$ of the population with the highest income (the top quintile) to that received by the $20 \%$ of the population with the lowest income (the bottom quintile)". The two mentioned indicators of inequalities give the whole picture of inequalities. Moreover, Eurostat offers the longest time series for these measures.

\subsection{Socio-economic development}

In the literature there is no compromise on the definition of socio-economic development. The author of the paper tried to conceptualize this phenomenon. On the basis of the literature review (among others: Kupiec [1995], Fritz [2004], Bobrowska and Piasecka [2005], Kompa [2009], Kubiczek [2014]), the author adopted the following definition of socio-economic development: this is a process of qualitative, quantitative, and structural changes. These modifications are consequences of the subjects' actions that are taken within economic practice. The changes take place in the following fields: material standard of living (possibility to satisfy needs associated with consumption of goods and services [economic growth], housing conditions, possibility to make ends meet), economic structure and entrepreneurship (investments, employment, innovations, access to public goods and services (that results in changes of education level, the way of taking care of someone's health etc.), natural environment (waste, $\mathrm{CO}_{2}$ emission) and life satisfaction (associated with material conditions of life).

The large number of dimensions of socio-economic development is an obstacle in measuring this phenomenon - a common standard in economics is lacking. There are only different indicators proposed that could be treated as attempts to measure socio-economic development. The most popular is the Human Development Index (HDI) that is developed on the basis of three criteria: long and healthy life, knowledge (education), appropriate standard of living [UNDP 2016]. Other indicators based on HDI, stress different aspects of socio-economic development, for example: Gender-Related Development Index, Gender Inequality Index [UNDP 2016], Human Poverty Index [UNDP 1996], Physical Quality of Life Index [UNDP 2012].

These measures allow to describe the level of socio-economic development, nevertheless they have some critical disadvantages. Firstly, they usually encompass only few aspects of the considered phenomenon, however there is a growing belief nowadays that an indicator of socio-economic development should consist of more variables [Milenkovic et al. 2014; Kompa 2009]. Secondly, popular measures concentrate on the material standard of living and financial categories, like income (in HDI it accounts for one-third of the measure). Thirdly, the time series for the proposed indicators are often short and non-continuous which is a major obstacle in econometric analysis.

Because of these disadvantages, the author of the article decided to develop his own synthetic measure of socio-economic development, using the method of 
Table 1. Diagnostic variables for a measure of socio-economic development

\begin{tabular}{|c|c|c|c|c|}
\hline Indicator & 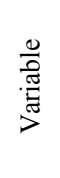 & 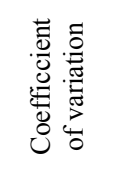 & 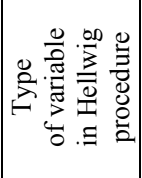 & 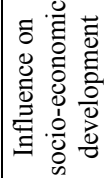 \\
\hline $\begin{array}{l}\text { Gross domestic product at market prices; chain linked volumes, } \\
\text { percentage change, per capita }\end{array}$ & v1 & $208.26 \%$ & isolated & $\mathrm{S}$ \\
\hline $\begin{array}{l}\text { Final consumption expenditure; chain linked volumes, percentage } \\
\text { change, per capita }\end{array}$ & $\mathrm{v} 2$ & $220.35 \%$ & isolated & $\mathrm{S}$ \\
\hline $\begin{array}{l}\text { Total population without a bath or a shower, and no indoor flushing } \\
\text { toilet in their household }\end{array}$ & v3 & $203.43 \%$ & satellite & \\
\hline $\begin{array}{l}\text { People living in households with very low work intensity (population } \\
\text { aged } 0 \text { to } 59 \text { years) }\end{array}$ & $\mathrm{v} 4$ & $34.80 \%$ & isolated & $\mathrm{D}$ \\
\hline $\begin{array}{l}\text { Average number of rooms per person by type of household and income } \\
\text { group from } 2003\end{array}$ & v5 & $24.62 \%$ & central & $\mathrm{S}$ \\
\hline Inability to face unexpected financial expenses & v6 & $39.56 \%$ & satellite & \\
\hline $\begin{array}{l}\text { Inability to make ends meet (Households making ends meet with great } \\
\text { difficulty) }\end{array}$ & v7 & $71.80 \%$ & satellite & \\
\hline Total investment to GDP ratio & v8 & $18.80 \%$ & central & $\mathrm{S}$ \\
\hline $\begin{array}{l}\text { Employment and activity by gender and age - annual data (as percentage } \\
\text { of population) }\end{array}$ & v9 & $7.37 \%$ & & \\
\hline $\begin{array}{l}\text { Unemployment by gender and age - annual data (as percentage of active } \\
\text { population) }\end{array}$ & v10 & $46.86 \%$ & central & $\mathrm{D}$ \\
\hline $\begin{array}{l}\text { Long-term unemployment by gender - annual average (as percentage of } \\
\text { active population) }\end{array}$ & v11 & $73.68 \%$ & satellite & \\
\hline $\begin{array}{l}\text { Intramural R\&D expenditure (GERD) - Percentage of gross domestic } \\
\text { product (GDP) }\end{array}$ & v12 & $58.45 \%$ & satellite & \\
\hline Total R\&D personnel, as $\%$ of total employment & v13 & $41.71 \%$ & satellite & \\
\hline R\&D researchers, as $\%$ of total employment & & $43.79 \%$ & satellite & \\
\hline Final energy consumption (index, $2005=100$ ) & v14 & $7.06 \%$ & & \\
\hline Share of energy from renewable sources in gross final energy consumption & v15 & $70.37 \%$ & isolated & $\mathrm{S}$ \\
\hline Greenhouse gas emissions, base year 1990 & v16 & $31.94 \%$ & satellite & \\
\hline Healthy life years in absolute value at birth - females & $\mathrm{v} 17$ & $7.67 \%$ & & \\
\hline Healthy life years in absolute value at birth - males & v18 & $7.94 \%$ & & \\
\hline Self-perceived health (very good) & v19 & $48.53 \%$ & isolated & $\mathrm{S}$ \\
\hline Self-perceived health (very bad) & $\mathrm{v} 20$ & $52.21 \%$ & isolated & $\mathrm{D}$ \\
\hline $\begin{array}{l}\text { Self-reported unmet needs for medical examination (reason: Too } \\
\text { expensive or too far to travel) }\end{array}$ & v21 & $91.67 \%$ & satellite & \\
\hline $\begin{array}{l}\text { Self-reported unmet needs for medical examination (reason: No unmet } \\
\text { needs to declare) }\end{array}$ & v22 & $5.72 \%$ & & \\
\hline Early leavers from education and training & $\mathrm{v} 23$ & $55.97 \%$ & isolated & \\
\hline Tertiary educational attainment & v24 & $31.51 \%$ & satellite & $\mathrm{D}$ \\
\hline Employment rates of recent graduates & $\mathrm{v} 25$ & $8.24 \%$ & & \\
\hline Adult participation in learning & v26 & $74.90 \%$ & satellite & \\
\hline Young people not in employment or in education and training & $\mathrm{v} 27$ & $33.76 \%$ & satellite & \\
\hline Recorded offences by offence category - police data & $\mathrm{v} 28$ & $81.75 \%$ & satellite & \\
\hline $\begin{array}{l}\text { Share of total population reporting problems with crime, violence or } \\
\text { vandalism in the area they live }\end{array}$ & v29 & $39.7 \%$ & isolated & $\mathrm{D}$ \\
\hline $\begin{array}{l}\text { Material deprivation rate for the 'Economic strain' and 'Durables', by } \\
\text { number of item of deprivation }\end{array}$ & v34 & 0 & ite & \\
\hline Severe housing deprivation rate & $\mathrm{v} 35$ & $95.98 \%$ & central & $\bar{D}$ \\
\hline
\end{tabular}

* S - stimulant; D - destimulant.

Source: own estimation. 
multidimensional comparison analysis. This indicator encompasses all the aspects that were mentioned in the definition of the phenomenon. Such a measure enables us to analyse socio-economic development better than ever before as it is broader than the indicators developed so far.

A synthetic measure was estimated in four steps - according to the method described by Panek [2007], Guzik, Appenzeller and Jurek [2007], Panek and Zwierzchowski [2013]. First of all, a set of diagnostic variables was chosen, along with merit and formal (statistical) criteria. As concerns the former, the initial set of indicators was designed on the basis of literature review in [Litwiński 2015] and shown in Table 1. This list was verified on the basis of statistical methods: a discrimination analysis and an evaluation of the information capacity of variables. Regarding the former, the value of the coefficient of variation was assessed variables with a value below 10\% were excluded [Panek, Zwierzchowski 2013]. In order to verify the information capacity of variables, we used the Hellwig [1968] procedure that is based on correlation analysis (details are indicated in the paper of this statistician, so there is no need to describe them here). For further estimations, only central and isolated variables were taken.

Secondly, indicators were divided into two groups: stimulants (phenomena that influence socio-economic development positively) and destimulants (phenomena that have a negative influence on socio-economic development). The character of variables was indicated in the last column of Table 1, only indicators that were not rejected in the previous part of analysis were taken into consideration. Destimulants were transformed using a multiplicative inverse that is the most popular method in such cases [Gatnar, Walesiak 2004].

Thirdly, variables were transformed by unitarization:

$$
z_{i j}=\frac{x_{i j}-\min _{i}\left\{x_{i j}\right\}}{\max _{i}\left\{x_{i j}\right\}-\min _{i}\left\{x_{i j}\right\}}
$$

where: $z_{i j}$ - normalized value of variable $j$ in object $i, x_{i j}$ - original value of variable $j$ in object $i$, values of indicators that were recalculated in this way range from 0 to 1 and have a more intuitive interpretation.

Fourthly, variables were aggregated using the following formula [Guzik et. al. 2007; Panek, Zwierzchowski 2013]:

$$
s_{i}=\frac{1}{m} \sum_{j=1}^{m} z_{i j} w_{j}
$$

where: $s_{i}$ - value of synthetic measure in object $i, z_{i j}$ - normalized value of variable $j$ in object $i, w_{j}$ - weight for variable $j$, estimated according to procedure BVP, described by Panek [2007].

Such an aggregation formula is the most popular in economic research that engages methods of comparison analysis [Panek, Zwierzchowski 2013]. 
The indicator calculated according to the procedure that was described above covers the range $<0 ; 1>$. The higher the value of a measure, the higher the level of socio-economic development.

\section{Previous studies of the influence of income inequalities on aspects of socio-economic development}

The research presented in the literature so far allowed to confirm that income inequalities influence the following aspects of socio-economic development (understood in the way that was described in the previous part of the article): (1) economic growth [Thorbecke, Charumilind 2002; Galor 2000; Persson, Tabellini 1994; Fay 1993], (2) education [Alesina et al. 2004; Birdsall 1999], (3) health (physical and mental welfare) [Wilkinson 1996; Wildman 2003; Brunner, Marmot 1999], (4) life satisfaction [Cole et al. 1992; Hopkins, Kornienko 2010], (5) crime [Van Wilsem 2004; Becker 1993; Shaw, McKay 1942], (6) natural environment [Boyce 1994].

Table 2. Quantitative analyses of the influence of income inequalities on economic growth

\begin{tabular}{|c|c|c|c|}
\hline Author of the research & $\begin{array}{l}\text { Method } \\
\text { of analysis }\end{array}$ & $\begin{array}{l}\text { Number } \\
\text { of countries }\end{array}$ & $\begin{array}{c}\text { Conclusions regarding the influence } \\
\text { of income inequalities on socio-economic } \\
\text { development }\end{array}$ \\
\hline [Alesina, Rodrik 1994] & \multirow[t]{2}{*}{$\begin{array}{l}\text { Cross-sectional } \\
\text { regressions }\end{array}$} & 70 & \multirow[t]{5}{*}{$\begin{array}{l}\text { Income inequalities have a negative influence } \\
\text { on socio-economic development }\end{array}$} \\
\hline [Perotti 1994] & & 71 & \\
\hline [Persson, Tabellini 1994] & Panel model & 9 & \\
\hline [Knack, Keefer 1997] & \multirow{4}{*}{$\begin{array}{l}\text { Cross-sectional } \\
\text { regressions }\end{array}$} & 56 & \\
\hline [Perotti 1994] & & 67 & \\
\hline [Benhabib-Spiegel 1994] & & 40 & \multirow{2}{*}{$\begin{array}{l}\text { Income inequalities do not have an influence } \\
\text { on socio-economic development }\end{array}$} \\
\hline [Deininger, Squire 1998] & & 46 & \\
\hline [Li, Zou 1998] & \multirow{3}{*}{$\begin{array}{l}\text { Panel model } \\
\text { with fixed } \\
\text { effects }\end{array}$} & 46 & \multirow{2}{*}{$\begin{array}{l}\text { Income inequalities have a positive influence } \\
\text { on socio-economic development }\end{array}$} \\
\hline [Forbes 2000] & & 45 & \\
\hline [Milanovic 2002] & & 24 & $\begin{array}{l}\text { Income inequalities have a negative influence } \\
\text { on socio-economic development }\end{array}$ \\
\hline [Tanninen 1999] & \multirow{4}{*}{$\begin{array}{l}\text { Cross-sectional } \\
\text { regressions }\end{array}$} & 52 & \multirow{2}{*}{$\begin{array}{l}\text { Income inequalities have a negative influence } \\
\text { on socio-economic development }\end{array}$} \\
\hline [Knell 1999] & & 83 & \\
\hline [Rehme 2002] & & 34 & $\begin{array}{l}\text { Income inequalities have a negative influence } \\
\text { on socio-economic development in high- } \\
\text { income countries }\end{array}$ \\
\hline $\begin{array}{l}\text { [Ostry, Berg, Tsangarides } \\
\text { 2014] }\end{array}$ & & 153 & $\begin{array}{l}\text { Alleviation of income inequalities has a } \\
\text { positive influence on economic growth }\end{array}$ \\
\hline [Barro 2000] & $\begin{array}{l}\text { Panel model } \\
\text { with random } \\
\text { effects }\end{array}$ & 46 & $\begin{array}{l}\text { Income inequalities have a negative influence } \\
\text { on socio-economic development in low- } \\
\text { income countries and a positive effect in } \\
\text { high-income countries }\end{array}$ \\
\hline
\end{tabular}

Source: literature review on the basis of the indicated references. 
The analyses of the relationship between income inequalities and socioeconomic development that are listed above do not have an overall character; there was research on particular fragments of the scientific scope of relation that is the subject of this paper, e.g. explaining only the influence of income inequalities on economic growth or the meaning of income dispersion for the distribution of educational opportunities. Therefore the studies mentioned above have rarely taken into account the interactions between social and economic aspects (elements) of different aspects of the socio-economic development. Moreover, studies on the influence of income inequalities on the social dimensions of the latter (e.g. health, life satisfaction) are conducted using mainly qualitative methods.

In the context of this paper it is useful to review the quantitative analyses that have been carried out so far in order to obtain knowledge about the methods which were used by other scientists. The research based on econometric tools is presented mainly in papers concerning the influence of income inequalities on economic growth. The results of these studies are shown in Table 2. On the basis of the majority of analyses, it could be realized that income inequalities have a negative influence on economic growth. The most popular method of research was regression for cross-sectional data. The author of this paper decided to use a more advanced tool, the panel model, analyzing the relationship between income inequalities and s category broader than economic growth - socio-economic development.

\section{Empirical analysis of the influence of income inequalities on socio-economic development}

The empirical research of relationship that is the subject of this paper was conducted for the European Union in the years 2004-2017. The variables that were taken into account are the synthetic indicator of socio-economic development which was estimated in the previous part of the article (dependent variable) and measures of income inequalities: the Gini coefficient and S80/S20 ratio (independent variables).

For each indicator of income dispersion a separate model was estimated. Such a solution is a consequence of the fact that both measures represent the same phenomenon, so they contain similar information i.e. the correlation coefficient between them (in the EU in the period 2004-2017) is 0.86. Additionally, the estimation of two separate models allows to indicate the aspect of income inequalities (dispersion for the whole distribution or the gap between the richest and the poorest) that has a stronger effect on socio-economic development.

In the paper we used the following abbreviations of variables' names: development - socio-economic development, Gini - Gini coefficient, S80/S20 modified income quintile share ratio. The models are estimated using Gretl software. In all the conducted tests the significance level is equal to 0.05 . 
The method that was used to recognize the character of influence of income inequalities on socio-economic development was panel data analysis. However before estimating the model, the data should be verified in order to ensure that it is of good quality. One of the serious problems in the time series could be unit root (non-stationarity of time series) that is often a reason for spurious regression, a situation in which the model seems to be correct but the relation between the analyzed phenomena does not exist in economic practice.

A non-stationary time series could be generated by a model of random walk with drift or a model with trend. The kind of model for a particular variable is the basis for the decision on the way of transforming the variables. In the case of random walk, differences should be calculated first, while the second model requires removing the trend [Charemza, Deadman 1997; Kusidel 2000; Maddala 2008; Nelson, Kang 1984]. The author decided to use the filter proposed by Hodrick and Prescott [1997].

The source of unit root was recognized on the basis of the test proposed by Dickey and Fuller [1981]. Within the procedure, we estimated the following model:

$$
\Delta y_{t}=\alpha_{0}+\delta \alpha_{1} t+\delta y_{t-1}+\sum_{i=1}^{k} \gamma_{i} \Delta y_{t-i}+\epsilon_{t},
$$

where: $\Delta y_{t}$ - first difference; equal to $y_{t}-y_{t-1}, y_{t-i}-$ value of variable in the period t-i, $t$ - time variable, $\alpha_{0}, \alpha_{1}, \delta, \gamma_{i}$ - parameters.

In such an equation, stochastic and deterministic trends are taken into account. Therefore the null hypothesis states that time series is generated by a model of random walk with $\operatorname{drift}(\delta=0)$, while the alternative hypothesis says that time series is a realization of a model with trend $(\delta<0)$. Test statistics have a distribution proposed by Dickey and Fuller [1981] and are calculated according to the formula suggested by the authors.

The results of the above procedure are presented in Table 3. All the variables are generated by the model with trend. The time series were transformed using the Hodrick-Prescott filter.

Table 3. Results of the ADF test for cross-sectional data from the EU in 2004-2017

\begin{tabular}{|l|c|c|l|l|}
\hline \multicolumn{1}{|c|}{ Variable } & $\begin{array}{c}\text { Number } \\
\text { of lags }(k)\end{array}$ & p-value & $\begin{array}{l}\text { Conclusions on } \\
\text { null hypothesis }\end{array}$ & $\begin{array}{c}\text { Conclusions on the model that } \\
\text { generates time series }\end{array}$ \\
\hline development & 2 & 0.00 & Reject & Model with trend \\
\hline Gini & 1 & 0.00 & Reject & Model with trend \\
\hline S80/S20 & 3 & 0.00 & Reject & Model with trend \\
\hline
\end{tabular}

Source: own estimation.

The choice of econometric method that was used to recognize the character of the influence of income inequalities on socio-economic development in the European 
Union, the panel model, was the result of review of analyses conducted so far (Table 2). The analysis of cross-sectional data is some kind of standard in research on the effect of income dispersion on one of the aspects of socio-economic development, economic growth. Besides, the panel model is a useful econometric tool in the analysis of short time series (as in this paper), because it allows to take into account cross-sectional data, data for different objects (mainly countries or regions) and in time. Increasing the number of observations enables the researcher to take into consideration the relations between the objects. Additionally, thanks to rise of dataset, dispersion is growing, which decreases the risk of collinearity, moreover estimates of the parameters are more accurate [Muszyńska 2006; Maddala 2008].

In this paper we considered four types of panel model: with fixed effects, with fixed and time effects, with random effects, with random and time effects. Each model, regardless of the specification, is expressed by the formula:

$$
y_{i t}=\alpha+\beta x_{i t}+u_{i t}
$$

while:

$$
u_{i t}=\mu_{i}+\lambda_{t}+v_{i t}
$$

where: $y_{i t}-$ dependent variable in object $i$ and period $t, x_{i t}$-independent variable in object $i$ and period $t, \alpha_{i}, \beta$ - parameters of a model, $u_{i t}$ - random component, $\mu_{i}$ - individual effect for object (country), $\lambda_{t}-$ time effect, $v_{i t}-$ the rest of random component, generated by a purely random process.

The model with fixed effects is based on the assumption that individual effects $\mu_{i}$ are constant parameters for the particular analyzed object [Baltagi 2001]. In order to check if such specification is correct, the Breusch-Pagan test is used. The null hypothesis of this procedure says that a variation of individual effects is equal to $0\left(\mu_{1}=\mu_{2}=\cdots=\mu_{T}=\mu\right.$, czyli $\left.\sigma_{\mu}^{2}=0\right)$. Rejection of this hypothesis means that the model is appropriate for the analyzed dataset [Maddala 2008].

In the model with random effects, it is assumed that individual effect $\mu_{i}$ is generated by a random variable with known distribution [Baltagi 2001]. The test proposed by Hausman allows to check if such specification is correct. It has null hypothesis about the lack of correlation between individual effects $\mu_{i}$ and independent variable $x_{i t}$. Rejection of this hypothesis means that the model should not be used.

An additional specification for both types of model is the introduction of time effects. In this class of models, time effects $\lambda_{t}$ are constant for each object in a particular period. In order to check if time effects are necessary, we could use the Wald test with null hypothesis saying that the dummy variables for time are insignificant. Rejection of this hypothesis means that the introduction of time effects is justified [Maddala 2008].

The quality of the model that was chosen on the basis of the mentioned procedures was verified by two tests. Firstly, the significance of the independent 
variable was tested, using the procedure proposed by Gosset [1908] (Student t-test) with null hypothesis about the lack of influence of the independent variable on the dependent variable. Secondly, the test of Ljung and Box [1978] was employed. This procedure has null hypothesis saying that the random component is not autocorrelated.

The results of the tests that allow to choose the correct specification of the model for the synthetic indicator of socio-economic development and the Gini coefficient are presented in Tables 4 and 5. The model with random effects and time effects is the most appropriate here. This is confirmed not only by the results of the respective tests but also by the values of information criteria - there were analyzed indicators proposed by Akaike [1974], Hanan-Quinn [1979] and Schwarz [1978].

Table 4. Results of the Breusch-Pagan and Hausman tests for a synthetic indicator of socio-economic development and the Gini coefficient

\begin{tabular}{|c|c|c|c|}
\hline & Model with fixed effects & Model with random effects \\
\hline \multicolumn{2}{|l|}{ Test } & Breusch-Pagan & Hausman \\
\hline \multicolumn{2}{|l|}{ p-value } & 0.09 & 0.36 \\
\hline \multicolumn{2}{|c|}{ Conclusion about $\mathrm{H} 0$} & Accept & Accept \\
\hline \multirow[t]{3}{*}{ Inf. criteria } & Akaike & -2396.60 & -2433.39 \\
\hline & Hanan-Quinn & -2350.96 & -2430.25 \\
\hline & Schwarz & -2281.44 & -2425.45 \\
\hline \multicolumn{2}{|c|}{ Conclusion about a model } & INAPPROPRIATE & APPROPRIATE \\
\hline
\end{tabular}

Source: own estimation.

Table 5. Results of the Wald tests for a synthetic indicator of socio-economic development and the Gini coefficient

\begin{tabular}{|c|c|c|c|}
\hline \multicolumn{2}{|l|}{ Tont } & \multicolumn{2}{|l|}{ Model with time effects } \\
\hline \multicolumn{2}{|l|}{ Test } & \multicolumn{2}{|l|}{ Wald } \\
\hline \multicolumn{2}{|l|}{ p-value } & \multicolumn{2}{|l|}{$1.89 \mathrm{E}-87$} \\
\hline \multicolumn{2}{|c|}{ Conclusion about $\mathrm{H} 0$} & \multicolumn{2}{|l|}{ Reject } \\
\hline \multirow[t]{4}{*}{ Inf. criteria } & & $\begin{array}{l}\text { For model with random effects } \\
\text { without time effects }\end{array}$ & $\begin{array}{l}\text { For model with random effects } \\
\text { and time effects }\end{array}$ \\
\hline & Akaike & -2433.39 & -2708.91 \\
\hline & Hanan-Quinn & -2430.25 & -2685.30 \\
\hline & Schwarz & -2425.45 & -2649.34 \\
\hline \multicolumn{2}{|c|}{ Conclusion about a model } & INAPPROPRIATE & APPROPRIATE \\
\hline
\end{tabular}

Source: own estimation.

Table 5 contains the outcomes of the estimation of the panel model for the Gini coefficient and an indicator of socio-economic development. According to the results, the parameter for the independent variable is insignificant. Income inequalities, measured for the whole distribution of income, do not influence socioeconomic development in the European Union in 2004-2017. 
Table 6. Results of estimation of the panel model for a synthetic indicator of socio-economic development and the Gini coefficient in the European Union in 2004-2017

\begin{tabular}{|l|l|l|l|}
\hline \multicolumn{2}{|c|}{ Criterion } & \multicolumn{2}{c|}{ Estimations } \\
\hline Parameters & \multicolumn{1}{|c|}{ Constant } & -3,42E-05 \\
\cline { 2 - 4 } & Estimation & 0.04 & 0.75 \\
\hline Student t-test & p-value & Accept \\
\cline { 2 - 4 } & Conclusion about H0 & $\begin{array}{l}\text { Income inequalities, measured by the Gini } \\
\text { coefficient, do not influence socio-economic } \\
\text { development. measured by synthetic indicator }\end{array}$ \\
\cline { 2 - 4 } & $\begin{array}{l}\text { Conclusion about influence of } \\
\text { independent variable }\end{array}$ & 0.36 \\
\hline \multirow{2}{*}{$\begin{array}{l}\text { Ljung-Box } \\
\text { autocorrelation } \\
\text { test }\end{array}$} & p-value & Accept \\
\cline { 2 - 4 } & Conclusion about H0 & Random component is not autocorrelated \\
\cline { 2 - 3 }
\end{tabular}

Source: own estimation.

Tables 7 and 8 contain the results of the tests that allow to choose the correct model for a synthetic indicator of socio-economic development and S80/S20 ratio. In this case the specification with random effects and time effects is also appropriate for the analyzed data. The Breusch-Pagan, Hausman and Wald tests

Table 7. Results of the Breusch-Pagan and Hausman tests for a synthetic indicator of socio-economic development and $\mathrm{S} 80 / \mathrm{S} 20$ ratio

\begin{tabular}{|c|c|c|c|}
\hline \multicolumn{2}{|l|}{ Test } & Model with fixed effects & Model with random effects \\
\hline \multicolumn{2}{|l|}{ Test } & Breusch-Pagan & Hausman \\
\hline \multicolumn{2}{|l|}{ p-value } & 0.09 & 0.39 \\
\hline \multicolumn{2}{|c|}{ Conclusion about H0 } & Accept & Accept \\
\hline \multirow[t]{3}{*}{ Inf. criteria } & Akaike & -2396.53 & -2433.38 \\
\hline & Hanan-Quinn & -2350.88 & -2430.24 \\
\hline & Schwarz & -2281.36 & -2425.44 \\
\hline \multicolumn{2}{|c|}{ Conclusion about a model } & INAPPROPRIATE & APPROPRIATE \\
\hline
\end{tabular}

Source: own estimation.

Table 8. Results of the Wald tests for a synthetic indicator of socio-economic development and S80/S20 ratio

\begin{tabular}{|c|c|c|c|}
\hline & & Model witl & time effects \\
\hline Test & & Wald & \\
\hline$p$-value & & $1.33 \mathrm{E}-87$ & \\
\hline Conclusion & ut $\mathrm{HO}$ & Reject & \\
\hline Inf. criteria & & $\begin{array}{l}\text { For model with random effects } \\
\text { without time effects }\end{array}$ & $\begin{array}{l}\text { For model with random effects } \\
\text { and time effects }\end{array}$ \\
\hline & Akaike & -2433.38 & -2708.91 \\
\hline & Hanan-Quinn & -2430.24 & -2685.30 \\
\hline & Schwarz & -2425.44 & -2649.34 \\
\hline Conclusion & but a model & INAPPROPRIATE & APPROPRIATE \\
\hline
\end{tabular}

Source: own estimation. 
enable us to say that the model is correct, also the values of the Akaike, HananQuinn and Schwarz criteria indicate that the loss of information is the lowest for this specification.

Table 9. Results of estimation of the panel model for a synthetic indicator of socio-economic development and S80/S20 ratio in the European Union in 2004-2017

\begin{tabular}{|l|l|l|l|}
\hline \multicolumn{2}{|c|}{ Criterion } & \multicolumn{2}{c|}{ Estimations } \\
\cline { 2 - 4 } & Estimation & constant & Gini \\
\hline \multirow{3}{*}{ Student t-test } & p-value & 0.04 & $-0,0002$ \\
\cline { 2 - 4 } & Conclusion about H0 & 0.01 & Reject \\
\cline { 2 - 4 } & $\begin{array}{l}\text { Conclusion about influence } \\
\text { of independent variable }\end{array}$ & $\begin{array}{l}\text { Income inequalities, measured by S80/S20 ratio, } \\
\text { influence socio-economic development. measured } \\
\text { by synthetic indicator }\end{array}$ \\
\hline $\begin{array}{l}\text { Ljung-Box } \\
\text { autocorrelation } \\
\text { test }\end{array}$ & p-value & 0.54 \\
\cline { 2 - 4 } & Conclusion about H0 & Accept \\
\cline { 2 - 4 } & $\begin{array}{l}\text { Conclusion about } \\
\text { autocorrelation }\end{array}$ & Random component is not autocorrelated \\
\hline
\end{tabular}

Source: own estimation.

The results of the estimation of the panel model for measuring socio-economic development and S80/S20 ratio are presented in Table 9. On the basis of Student's t-test, it could be said that income quintile share ratio influences significantly the indicator of socio-economic development. Thus the income gap between the richest and the poorest (contrary to inequalities measured for the whole distribution) affects socio-economic development in the European Union in the years 20042017. The character of this influence is negative as the concentration of incomes hinders socio-economic de-velopment.

The model is of good quality. Firstly, the values of information criteria are low. Secondly, according to the Ljung-Box test, random component is not autocorrelated.

\section{Conclusions}

The analysis presented in the paper leads to ambiguous conclusions. On the one hand, income inequalities measured for the whole distribution of income have no influence on socio-economic development in the European Union. However, income gap between the richest and the poorest hinders the mentioned phenomenon.

Thus the hypothesis of the article should not be accepted unequivocally. Only the differences between groups with high and low incomes could be said to have a negative impact on socio-economic development in the EU.

Such conclusions about the character of influence have their limitations. The results of econometric analysis depend on the chosen econometric tool and the 
variables that are taken into account. Therefore the study presented in the paper could be treated only as an attempt to recognize the character of impact of income inequalities on socio-economic development in the European Union.

Further research could identify elements of socio-economic development that are affected by income inequalities more strongly than the others, also recognizing the period in which the time effect in the panel model appeared.

\section{Bibliography}

Akaike H., 1974, A new look at the statistical model identification, IEEE, vol. 19, no. 6.

Alesina A., Rodrik D., 1994, Distributive politics and economic growth, Quarterly Journal of Economics, vol. 109, no. 2, pp. 465-490.

Alesina A., Tella R.D., MacCulloch R., 2004, Inequality and happiness: Are Europeans and Americans different?, Journal of Public Economics, vol. 88, no. 9-10.

Allison P., 1978, Measures of inequality, American Sociological Review, vol. 43, issue: 6, pp. 865-880 .

Amiel Y., Cowell F., 1992, Measurement of income inequality: Experimental test by questionnaire, Journal of Public Economics, vol. 47, pp. 3-26.

Baltagi B., 2001, Econometric Analysis of Panel Data, John Wiley \& Sons Ltd., Chichester.

Barro R., 2000, Inequality and growth in a panel of countries, Journal of Economic Growth, vol. 5.

Becker G., 1993, Nobel lecture: The economic way of looking at behavior, J. of Pol. Econ., vol. 101.

Benhabib J., Spiegel M., 1994, The role of human capital in economic development. Evidence from aggregate cross-country data, Journal of Monetary Economics, vol. 34, pp. 143-173.

Birdsall N., 1999, Education: The people's asset, Working Paper, no. 5, CSED.

Bobrowska A., Piasecka A., 2005, Sytuacja społeczno-gospodarcza regionu a bezrobocie na przykładzie województwa opolskiego, [in:] Kopycińska, D. (ed.), Konkurencyjność rynku pracy i jego podmiotów, Katedra Mikroekonomii Uniwersytetu Szczecińskiego, Szczecin.

Boyce J., 1994, Inequality as a cause of environmental degradation, Ecological Economics, vol. 11, no. 3 .

Brandolini A., 2007, Measurement of income distribution in supranational entities: The case of the European Union, [in:] Jenkins S., Micklewright J. (eds.), Inequality and Poverty Reexamined, Oxford University Press, Oxford.

Brunner E., Marmot M., 1999, Social organization, stress and health, [in:] Marmot M., Wilkinson R.G. (eds.), Social Determinants of Health, Oxford University Press, Oxford.

Brzeziński, M., Kostro, K., 2010, Income and consumption inequality in Poland, 1998-2008, Bank i Kredyt, vol. 41, no. 4, pp. 45-72.

Charemza W.W., Deadman C.F., 1997, Nowa ekonometria, PWE, Warszawa.

Cole H., Mailath G., Postlewaite A., 1992, Social norms, savings behavior, and growth, Journal of Political Economy, vol. 100, no. 6.

Deininger S., Squire L., 1998, New ways of looking at old issues, Journal of Development Economics, vol. 57, pp. 259-287.

Dickey W., Fuller D., 1981, Likelihood ratio statistics for autoregressive time series with a unit root, Econometrica, vol. 49, no. 1.

European Union, 2003, Rozporządzenie (WE) Nr 1177/2003 Parlamentu Europejskiego i Rady z dnia 16 czerwca 2003 r. dotyczące statystyk Wspólnoty w sprawie dochodów i warunków życia (EU-SILC), Dziennik Urzędowy Unii Europejskiej.

Eurostat, 2018, Glossary: Income quintile share ratio, https://ec.europa.eu/eurostat/statisticsexplained/index.php?title=Glossary:Income_quintile_share_ratio (30.08.2018). 
Fay M., 1993, Illegal Activities and Income Distribution: A model of Envy, Columbia University, NY. Forbes K., 2000, A reassessment of the relationship between inequality and growth, American Economic Review, vol. 90, no. 4, pp. 869-887.

Fritz, J., 2004, Socioeconomic developmental social work, [in:] UNESCO Encyclopedia of Life Support Systems, A Project on Sustainable World Development, UNESCO-EOLSS, Oxford.

Galor O., 2000, Income distribution and the process of development, European Economic Review, vol. 44.

Gatnar E., Walesiak M. (eds.), 2004, Metody statystycznej analizy wielowymiarowej w badaniach marketingowych, Wydawnictwo Akademii Ekonomicznej we Wrocławiu, Wrocław.

Gosset W.S., 1908, The probable error of a mean, Biometrika, no. 6, pp. 1-25.

Guzik B., Appenzeller D., Jurek W., 2007, Prognozowanie i symulacje, Wydawnictwo Akademii Ekonomicznej, Poznań

Hannan B., Quinn E., 1979, The determination of the order of an autoregression, Journal of the Royal Statistical Society, vol. 41, no. 2

Hellwig Z., 1968, Zastosowanie metody taksonomicznej do typologicznego podziału krajów ze względu na poziom ich rozwoju, Przegląd Statystyczny, z. 4, pp. 307-327.

Hodrick R., Prescott E., 1997, Postwar US business cycles: An empirical investigation, Journal of Money, Credit, and Banking, vol. 29, no. 1, pp. 1-16.

Hopkins E., Kornienko T., 2010, Which inequality? The inequality of endowments vs. the inequality of rewards, American Economic Journal: Microeconomics, vol. 2, no. 3.

Knack S., Keefer, P., 1997, Does social capital have an economic payoff? A cross-country investigation, Quarterly Journal of Economics, vol. 112, no. 4.

Knell M., 1999, Social Comparisions, Inequality, and Growth, Journal of Institutional and Theoretical Economics, vol. 155, no. 4, pp. 664-695.

Kompa K., 2009, Budowa mierników agregatowych do oceny poziomu rozwoju społeczno-gospodarczego, Ekonomika i Organizacja Gospodarki Żywnościowej, Zeszyty Naukowe SGGW, nr 74, pp. 5-26.

Kubiczek A., 2014, Jak mierzyć dziś rozwój społeczno-gospodarczy krajów?, Nierówności Społeczne a Wzrost Gospodarczy, vol. 2, no. 38, pp. 40-56.

Kupiec L., 1995, Rozwój społeczno-gospodarczy, Dział Wydawnictw Filii UW, Białystok.

Kusideł E., 2000, Modele wektorowo-autoregresyjne VAR. Metodologia i zastosowania, [in:] Suchecki B. (ed.), Dane panelowe i modelowanie wielowymiarowe, Absolwent, Łódź.

Li H., Zou H., 1998, Income inequality is not harmful for growth: Theory and evidence, Review of Development Economics, vol. 2, no. 3, pp. 318-334

Litwiński M., 2015, Nierówności dochodowe jako determinanta rozwoju spoteczno-gospodarczego w Unii Europejskiej, [in:] Luks K., Seredocha I. (ed.), Gospodarka i spoleczeństwo w europejskiej perspektywie, Elbląska Uczelnia Humanistyczno-Ekonomiczna, Elbląg, pp. 15-38.

Ljung G., Box G., 1978, On a measure of a lack of fit in time series, Biometrika, vol. 65, no. 2.

Maddala G.S., 2008, Ekonometria, Wydawnictwo Naukowe PWN, Warszawa

McKay A., 2002, Defining and measuring inequality, Inequality Briefing Paper No 1, Overseas Development Institute and University of Nottingham, Nottingham.

Milanovic B., 2002, True world income distribution, 1988 and 1993: First calculation based on household surveys alone, Economic Journal, vol. 112, no. 476, pp. 51-92.

Milenkovic N., Vukmirovic J., Bulajic M., Radojicic Z., 2014, A multivariate approach in measuring socio-economic development of MENA countries, Economic Modelling, vol. 38, pp. 604-608.

Muszyńska J., 2006, Modelowanie danych panelowych, https://repozytorium.umk.pl/handle/ item/5101 (30.08.2018).

Nelson C., Kang H., 1984, Pitfalls in the use of time as explanatory variable in regression, Journal of Business and Economic Statistics, vol. 2, pp. 73-82.

OECD, 2011, Divided We Stand: Why Inequality Keeps Rising., OECD

Ostry J., Berg A., Tsangarides C., 2014, Redistribution, Inequality and Growth, IMF. 
Panek T., 2007, Ubóstwo i nierówności, [in:] Panek T. (ed.), Statystyka społeczna, PWE, Warszawa.

Panek T., 2011, Ubóstwo, wykluczenie społeczne i nierówności. Teoria i praktyka pomiaru, Oficyna Wydawnicza SGH, Warszawa.

Panek T., Zwierzchowski J., 2013, Statystyczne metody wielowymiarowej analizy porównawczej. Teoria i zastosowania, Oficyna Wydawnicza SGH, Warszawa.

Perotti R., 1994, Income Distribution and Investment, European Economic Review, vol. 38.

Persson T., Tabellini G., 1994, Is inequality harmful for growth?, American Economic Review, vol. 84 , no. 3 , pp. $600-621$.

Rehme G., 2002, Education, economic growth and personal income inequality across (rich) countries, Working Paper, no. 300, Luxembourg Income Study.

Schwarz G., 1978, Estimating the dimension of a model, The Annals of Statistics, vol. 6, no. 2.

Shaw C., McKay H., 1942, Juvenile Delinquency and Urban Areas, University of Chicago, Chicago.

Subramanian S., 2004, Indicators of inequality and poverty, Research Paper, no. 2004/25, World Institute for Development Economics Research, United Nations University, Helsinki.

Tanninen H., 1999, Income inequality, government expenditures and growth, Applied Economics, vol. 31, no. 9, pp. 1109-1117.

Thorbecke E., Charumilind C., 2002, Economic inequality and its socioeconomic impact, World Development, vol. 30, no. 9 .

UNDP, 1996, Human Development Report 1996, Oxford University Press, Oxford.

UNDP, 2012, Krajowy raport o rozwoju społecznym. Polska 2012. Rozwój regionalny i lokalny, Biuro Projektowe UNDP w Polsce, Warszawa.

UNDP, 2016, Human Development Report 2016, Communications Development Inc., Washington.

Van Wilsem J., 2004, Criminal victimization in a cross-national perspective, European Journal of Criminology, vol. 1.

Wildman J., 2003, Modelling health, income and income inequality: The impact of income inequality on health and health inequality, Journal of Health Economics, vol. 22.

Wilkinson R., 1996, Unhealthy societies: The affliction of inequality, Routledge, London.

World Economic Forum (WEF), 2018, How can the world strengthen growth and equality at the same time?, https://www.weforum.org/system-initiatives/shaping-the-future-of-economic-growth (30.08.2018).

\section{WPLYW NIERÓWNOŚCI DOCHODOWYCH NA ROZWÓJ SPOŁECZNO-EKONOMICZNY W UNII EUROPEJSKIEJ}

Streszczenie: W ostatnich latach prowadzi się liczne analizy ilościowe wpływu rozwarstwienia dochodowego na aspekty rozwoju społeczno-ekonomicznego w krajach rozwiniętych. Brakuje jednak badań, które miałyby charakter kompleksowy. Wnioski z analizy tego typu mogłyby być istotną podstawą kształtowania polityki gospodarczej. Dlatego też problemem podjętym w opracowaniu jest wpływ nierówności dochodowych na poziom rozwoju społeczno-ekonomicznego. Cel artykułu stanowi weryfikacja hipotezy o negatywnym charakterze wspomnianej zależności w Unii Europejskiej. Analiza została przeprowadzona dla krajów Unii Europejskiej w latach 2004-2017 za pomocą modelu panelowego. Badanie prowadzi do niejednoznacznych rezultatów. Z jednej strony nierówności mierzone dla całego rozkładu dochodów nie mają wpływu na rozwój społecznoekonomiczny w Unii Europejskiej, z drugiej strony dystans między najbogatszymi i najbardziej ubogimi wpływa hamująco na ten proces.

Słowa kluczowe: nierówności dochodowe, rozwój społeczno-ekonomiczny, wzrost ekonomiczny, model panelowy, współczynnik Ginniego, wskaźnik S80/S20. 